\section{Strawberry Parent Clones US 70, US 159, US 292, and US 438 Resistant to Anthracnose Crown Rot}

\author{
G.J. Galletta ${ }^{1}$ \\ U.S. Department of Agriculture, Agricultural Research Service, Fruit \\ Laboratory, Plant Sciences Institute, Beltsville, MD 20705
}

\author{
B.J. Smith ${ }^{2}$ and C.L. Gupton ${ }^{1}$ \\ Small Fruit Research Station, P.O. Box 287, Poplarville, MS 39470
}

Additional index words. Fragaria $\times$ ananassa, Colletotrichum fragariae, Colletotrichum acutatum, fruit breeding, disease screening

The clones described in this germplasm release were originated during an extended cooperative team effort by U.S. Dept. of Agriculture (USDA) and state agricultural experiment station personnel to overcome anthracnose crown rot disease limitations on strawberry (Fragaria $\times$ ananassa Duch.) production in the southeastern United States. Our efforts to originate anthracnose-resistant strawberry germplasm started in 1975 with strawberry selection and fungal isolate contributions from the USDA, Univ. of Florida, Louisiana State Univ., and North Carolina State Univ. Breeding to develop regionally resistant host materials started at Beltsville, Md., in 1976 under the direction of A.D. Draper, who is now retired, and it has continued since 1977 under the direction of G.J.G. Starting in 1975, disease epidemiology information and isolate culture and inoculation techniques were developed in Poplarville, Miss., under the direction of B.J.S. (Smith and Black, 1987, 1990; Smith and Spiers, 1982; Smith et al., 1990).

Originally, anthracnose crown rot was thought to be incited by Colletotrichum fragariae Brooks (Bonde et al., 1991); however, $C$. acutatum Simmonds has incited severe strawberry fruit rot (Simmonds, 1965; Smith and Black, 1987). Colletotrichum gloeosporiodes (Penz.) Penz. \& Sacc. also may cause strawberry anthracnose crown and fruit rot (Smith and Black, 1990). Although all three fungal species may cause strawberry plant death, $C$. fragariae is the usual incitant in the U.S. Gulf Coast states, and C. acutatum is the principal anthracnose fruit rot incitant in this region (Howard et al., 1992).

Anthracnose crown rot resistance inheritance models were determined by Gupton and Smith (1991). In addition to showing a high

Received for publication 29 Sept. 1992. Accepted for publication 1 June 1993. We greatly appreciate the cooperation of James Augustine and Peggy Chang, BHN Corp., Bonita Springs, Fla., for evaluating US 70, US 159, and US 292 in southern Florida. The cost of publishing this paper was defrayed in part by the payment of page charges. Under postal regulations, this paper therefore must be hereby marked advertisement solely to indicate this fact. 'Research Geneticist.

${ }^{2}$ Research Plant Pathologist. degree of resistance to anthracnose crown rot (incited by $C$. fragariae), the clones we describe have near-commercial fruit quality and productivity. They likely will be useful parents for incorporating anthracnose crown rot resistance into strawberries adapted to other areas.

Data for plants grown in Poplarville were gathered and analyzed by B.J.S. We made morphological plant and fruit characterizations in 1991 at Poplarville using 1 to 9 scalar interval scores developed by G.J.G. The data in Beltsville were collected by G.J.G.

\section{Origins and descriptions}

US 70. Tested as MSUS 70, US 70 resulted from a cross made in 1979 at Beltsville between Florida selection 76-802 (FL 73-1965 x FL 73-780) and Louisiana selection 2556. Seedlings from the cross were inoculated in 1980 at Poplarville with $C$. fragariae isolates CF-1, CF-4, FLA-2, MS-9, and FLA-1. Resistant seedlings were grown at Poplarville, and US 70 was selected in 1981. US 70 was used by Smith and Black (1990) as a differentiating cultivar to separate races of $C$. fragariae and C. acutatum. In Mississippi hill culture trials, covered with spots.

${ }^{w} P=0.05$.
US 70 produced as well as the standard cultivar Tangi in 1990 and 1991, as well as 'Chandler' in 1990, and better than 'Chandler' during the abbreviated 1991 season (Table 1). US 70 fruit were later than and the same size as 'Tangi' fruit in 1990, but ripened with and were larger than those from 'Tangi' in 1991. US 70 fruit ripened with and were smaller than 'Chandler' fruit in 1990, but they ripened with and were larger than 'Chandler' in 1991 (Table 1).

The outstanding features of US 70 are high resistance levels to leaf spot [Mycosphaerella fragariae (Tul.) Lindau], leaf scorch [Diplocarpon earliana (Ell. \& Ev.) Wolf], powdery mildew [Sphaerotheca macularis (Wallr. ex Fr.) Jacz. f. sp. fragariae], anthracnose crown rot, and two-spotted mites (Tetranychus urticae Koch); good fruit quality; desirable, bright red, and large fruit; and an extended harvest season.

US 70 plants are medium-sized and compact, with medium-green leaves and three leaflets of equal size. Central leaflets curve down at the tips, and side leaflets curve up at the margins. Leaf serrations are rounded but pointed at the tip (Fig. 1). Veins on the leaf underside are prominent, and leaf petioles are light green and pubescent. Fruit of US 70 have a shouldered wedge shape with a blunt tip; narrow, pointed fruit cap sepals that are partially reflexed at maturity; and slightly raised yellow achenes (Fig. 1). US 70 fruit are firmfleshed, light pink internally, and juicy. They have a pleasant flavor that we judge to be sweet and acidic.

US 70 transmitted anthracnose resistance to $80 \%$ of its several progenies, and it likely will be a suitable disease-resistant parent for either winter or early spring hill culture production, or mid- to late spring matted row production. US 70 has been grown successfully at Poplarville, Beltsville, and Bonita Springs, Fla.

US 159. Tested as MSUS 159, US 159 resulted from a 1982 cross in Beltsville of two anthracnose-resistant selections, LA 7525-A $\times$ US 78-1760 AN (Florida Belle $\times$ LA 2556).

Table 1. Performance of strawberry selections and standard cultivars at Poplarville, Miss., 1990-91.

\begin{tabular}{|c|c|c|c|c|c|}
\hline \multirow[b]{2}{*}{ Clone } & \multicolumn{2}{|c|}{ Yield $\left(\mathrm{t} \cdot \mathrm{ha}^{-1}\right)$} & \multirow{2}{*}{$\begin{array}{l}\text { Berry wt } \\
\text { (g/berry) }\end{array}$} & \multirow[b]{2}{*}{ Vigor $^{y}$} & \multirow[b]{2}{*}{ Leaf spot } \\
\hline & Total & Early $(\%)^{2}$ & & & \\
\hline \multicolumn{6}{|c|}{1990} \\
\hline US 70 & 12.0 & 9.9 & 8.6 & 2 & 2 \\
\hline US 159 & 14.3 & 0.0 & 15.6 & 3 & 2 \\
\hline US 292 & 8.1 & 5.0 & 13.6 & 6 & 2 \\
\hline US 438 & 15.0 & 19.1 & 9.9 & 5 & 2 \\
\hline Tangi & 17.2 & 21.9 & 11.1 & 1 & 4 \\
\hline Chandler & 7.3 & 14.0 & 14.3 & 3 & 2 \\
\hline $\operatorname{LSD}^{\mathrm{w}}$ & 7.6 & 11.8 & 2.6 & 2 & 2 \\
\hline \multicolumn{6}{|c|}{1991 (Short season) } \\
\hline US 70 & 11.6 & 42.2 & 16.6 & 8 & 1 \\
\hline US 159 & 7.4 & 13.6 & 12.2 & 6 & 3 \\
\hline US 292 & 5.7 & 12.0 & 16.4 & 5 & 1 \\
\hline US 438 & 7.2 & 54.9 & 19.4 & 7 & 1 \\
\hline Tangi & 7.9 & 40.1 & 12.1 & 5 & 1 \\
\hline Chandler & 1.2 & 22.6 & 12.7 & 4 & 1 \\
\hline $\mathrm{LSD}^{W}$ & 4.4 & 33.7 & 3.4 & 2.2 & 2.6 \\
\hline
\end{tabular}

${ }^{z}$ That portion of the total crop that ripens in the first third of the season.

y 1990: 1 = least vigorous, 6 - most vigorous; 1991: $0=$ dead, $10=$ most vigorous.

${ }^{x} 1990: 1=$ no symptoms, $5=$ entire plant covered with spots; $1991: 0=$ no symptoms, $10=$ entire plant 
In 1983 in Poplarville, it was screened against a mixture of $C$. fragariae isolates, CF-1, CF-4, FL-2, LA-1, CF-75, and CF-CARD. US 159 has been tested in Poplarville, Beltsville, and Bonita Springs. It transmitted anthracnose resistance to $55 \%$ of its progenies and is notable for its fruit yield, size, color, leaf and fruit disease tolerance, vigor, good balance of fruit characteristics, and long ripening season (Table 1). US 159 may have some pollination problems in cool weather and some fruit cracking in wet weather.

US 159 plants are large, medium dense, productive, and resistant to anthracnose crown rot, leaf scorch, leaf blight [Phomopsis obscurans (Ell. \& Ev.) Sutton], powdery mildew, and two-spotted mites. Leaves are large with oblique bases, even on central leaflets; and prominent venation; and rounded, with marginal serrations that are pointed and broad. Petioles are thick and lightly pubescent (Fig. 1). From $10 \%$ to $30 \%$ of the leaves have four leaflets. Flowers have five to seven round, slightly overlapping petals; tall and concave receptacles; numerous stamens with small anthers borne on tall filaments; and 10 narrow and pointed sepals. Fruit are borne on long pedicels and have along, irregular conic shape with prominent yellow achenes (Fig. 1). US 159 fruit are firm, deep red outside, pink inside, and acidic. The caps vary from clasping to partially reflexed.

US 292. Tested as MSUS 292, US 292 came from a 1985 cross in Beltsville of Arking $\times$ LA 883. It was screened in 1986 against the aggressive and virulent CF-63 isolate of $C$. fragariae, and it was selected in 1988 in Poplarville. Southern Florida production of US 292 was lower than that of 'Chandler', but US 292 showed high resistance to anthracnose

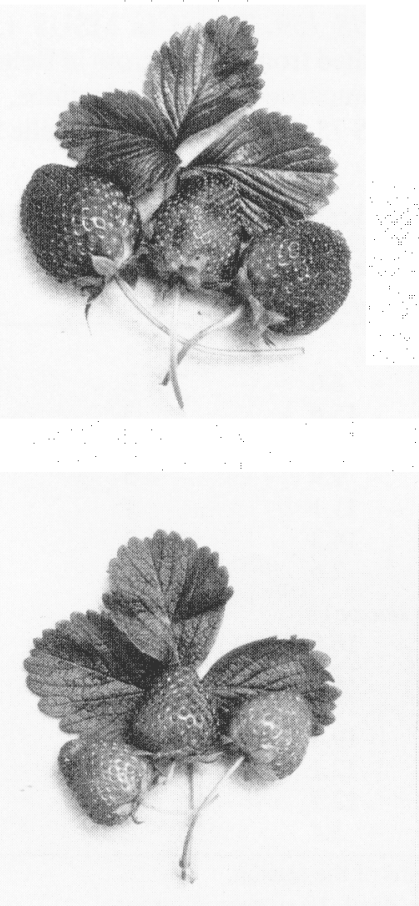
medium green with silver-green undersides

crown rot, two-spotted mites, leaf spot, and leaf scorch. It generally had good plant health and ability to generate runners. During the more normal 1990 season in Mississippi, US 292 yielded as well as 'Chandler' but less than 'Tangi' (Table 1); its fruit ripened later and its plants were more vigorous than either standard cultivar. US 292 fruit was larger than 'Tangi' fruit and the same size as 'Chandler' in 1990, but larger than either standard in 1991. In Maryland, US 292 was a promising latematuring clone in matted row production. It showed a fine balance of fruit and plant traits, producing an outstanding plant bed and fruit with superior size, symmetry, firmness, skin color and gloss, flesh color, and flavor.

US 292 plants are medium-sized with an open habit and are disease-free in the field. Its leaves are deep green on top, light green underneath, and slightly down-curved with prominent veins and hairy petioles (Fig. 1). US 292 fruit have firm skin and flesh, and are flavorful, aromatic, and slightly acidic. The fruit is short conic and medium-large in appearance, with slightly raised achenes. Its caps are large and showy; individual parts are lanceolate to ovate and acuminate, and partially reflexed at maturity (Fig. 1).

US 438. Tested as MSUS 438, US 438 resulted from across between resistant clones MSUS 56 \{LA $883 \times$ [Sunrise $\times$ (Midland $\times$ Albritton)] $\} \times$ MSUS $70($ FL 76-802 $\times$ LA $2556)$ in an anthracnose inheritance study at Poplarville. US 438 survived a natural greenhouse epiphytotic of $C$. fragariae in 1986 and has shown resistance to field infestations by the fungus since 1987. It was selected at Poplarville in 1988. Recent tests by North Carolina cooperators indicate that US 438 also is resistant to runner infection incited by $C$. acutatum. In Mississippi, US 438 has yielded

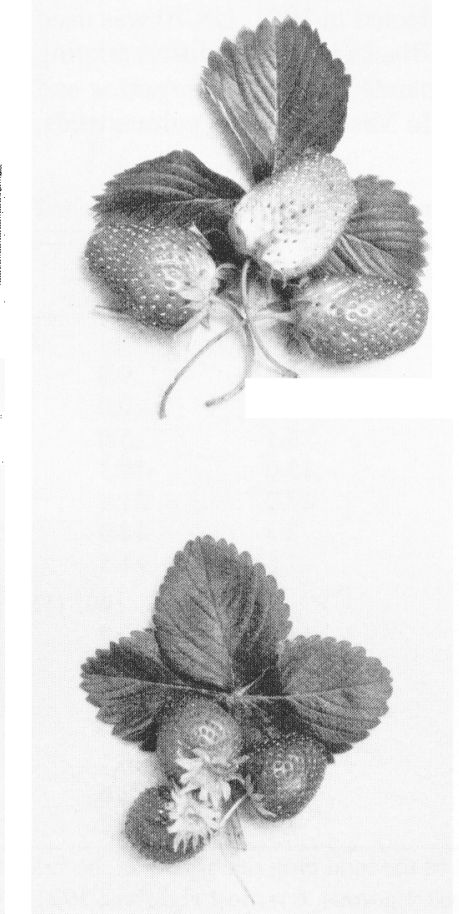

Fig. 1. Representative late-midseason fruit and leaves of anthracnose crown-rot-resistant strawberry germplasm releases: US 70 (top left), US 159 (top right), US 292 (bottom left), and US 438 (bottom right). as well as 'Tangi' and better than 'Chandler' (Table 1). It is earlier than either standard and had both smaller and larger fruit than the standard cultivars during two seasons. In matted row production in Maryland, US 438 was an average performer, ripening early and with generally good plant bed and fruit characters. Fruit symmetry and skin toughness were subpar, but plant stand, vigor, and fruit firmness were superior.

US 438 plants are large, dense, vigorous, and free of disease. Leaves are large and rugose, with leaflets turning down at the tip as they age. Leaves are medium to light green with light green undersides, and they have prominent main and branch veins. The leaves have sharply pointed serrations and pubescent petioles (Fig. 1), with hairs at a $90^{\circ}$ angle to the stem axis. Flower petals are rounded and overlapping, anthers are small with abundant pollen, stamens are erect, and sepals are narrow. US 438 fruit is dark scarlet and firm, has a dry consistency, and is acidic with a good flavor. Fruit shape is a long wedge with achenes flush to slightly raised; the cap is large, showy, and partially reflexed (Fig. 1). Following inoculation of plants at flowering with $C$. acutatum conidia, US 438 fruit showed no anthracnose fruit rot at Castle Hayne, N.C., early in the ripening season (21 Apr. 1992), while $70 \%$ of the 'Chandler' fruit was infected (James Ballington, North Carolina State Univ., personal communication).

\section{Availability}

Interested parties may request in vitro starter stocks (up to five per clone) of any or all of these selections from B.J. Smith, USDA Agricultural Research Service, Small Fruit Research Station, P.O. Box 287, Poplarville, MS 39470 (phone 601/795-8751, fax 601/7954965). The in vitro stocks were produced from apical meristem explants and maybe regarded as free of fungus and bacterial contaminants and presumably free of viruses.

\section{Literature Cited}

Bonde, M.R., G.L. Peterson, and J.L. Maas. 1991. Isozyme comparisons for identification of Colletotrichum species pathogenic to strawberry. Phytopathology 81:1523-1528.

Gupton, C.L. and B.J. Smith. 1991. Inheritance of resistance to Colletotrichum species in strawberry. J. Amer. Soc. Hort. Sci. 116:724-726.

Howard, C.M., J.L. Maas, C.K. Chandler, and E.E. Albregts. 1992. Colletotrichum diseases of strawberry in Florida Anthracnose. Plant Dis. 76:976-981.

Simmonds, J.H. 1965. A study of the species of Colletotrichum causing ripe fruit rots in Queensland. Queensland J. Agr. Animal Sci. 22:437-459.

Smith, B.J. and L.L. Black. 1987. Resistance of strawberry plants to Colletotrichum fragariae affected by environmental conditions. Plant Dis. 71:834-837.

Smith, B.J. and L.L. Black. 1990. Morphological, cultural, and pathogenic variation among Colletotrichum species isolated from strawberry. Plant Dis. 74:69-76.

Smith, B.J., L.L. Black, and G.J. Galletta. 1990. Resistance to Colletotrichum fragariae in strawberry affected by seedling age and inoculation method. Plant Dis. 74:1016-1021.

Smith, B.J. and J.M. Spiers. 1982. Evaluating techniques for screening strawberry seedlings for resistance to Colletotrichum fragariae. Plant Dis. 66:559-561. 